\title{
Research on Relevant Issues of Creditors' Interest Protection in Chinese Authorized Capital System
}

\author{
Xiaohua Liu \\ Law School, Dianchi College of Yunnan University, Kunming, 650228, China
}

\begin{abstract}
Keywords: Authorized capital system; Legal capital system; Company Law; Creditors' interest protection
\end{abstract}

\begin{abstract}
Protection of shareholders and creditors' interest is the important function and objective of corporate capital system. The Company Law of the People's Republic of China newly revised in 2014 modifies the compromise capital system as authorized capital system; although the efficiency is improved through this change, the protection on creditors' interests is weak. Due to late starting of Chinese authorized capital system, there exist many principal and system-related defects, which causes crisis in creditors' interest protection. However, the practical experience of authorized capital system in western countries can provide certain references to China. This paper aims at carrying out a discussion on perfecting legal system with respect to creditors' interest protection in Chinese authorized capital system.
\end{abstract}

\section{Introduction}

According to Company Law, as for the establishment of capital system, it is required to not only consider the cost value of establishment and flexible operation, but also consider the vital interests of participants such as directors/shareholders and creditors, thus it is a very complicated and important corporate legislation project and requires tacit understanding and mutual trust among corporate juridical persons, shareholders, and creditors. After the amendment to Company Law in 2005, the legal capital system is modified as compromise capital system, and then the compromise capital system is modified as authorized capital system after re-amendment in the end of 2013. The authorized capital system pays more attention to efficiency, thus it can promote the corporate development speed. However, China's specific national condition is different from the conditions in western countries. The fundamental condition that the authorized capital system depends on is relatively mature in western countries, but the implementation of authorized capital system in China lacks of certain supporting system as guarantee. Therefore, there exists the risk that the protection for creditors' interests is reduced behind the implementation of 2014 new company law. The legal system shall be further perfected for the purpose of guaranteeing creditors' interests.

\section{Legal capital system and authorized capital system}

\section{Authorized capital system}

The authorized capital system is a kind of corporate capital system which originates from common law system. It refers to the situation that a company can be officially established as long as partial corporate capital is paid in; as for the remaining part, the corporate board of directors will determine when to make issuing according to actual corporate operation condition and securities market. (1)

The authorized capital system makes the establishment of one company become more convenient and easier, and the company can be established under the condition that the corporate shareholders don't pay up the registered capital for once. The motivation to participants' investment enthusiasm and the intention of simplifying corporate establishment procedure under authorized capital system further highlight the corporate sponsors' self-oriented value thoughts which may be conflicting with corporate and external participants' long-term interests.

(1) Xudong,Zhao.Company Law(2008).Higher Education Press .at 229. 


\section{Legal capital system}

The legal capital system is also called determined capital system, and it refers to the situation that the shareholders shall pay up and issue the corporate capital sum for once while the company is established. (2)The legal capital system specifies the initial corporate capital amount, and requires that the company shall make one-off issuing before official establishment of company to realize all paid-up or fully-subscription of capital, which is a rigid index at the initial establishment of company. Furthermore, the legal capital system emphasizes "legal", and it requires that the capital shall be determined and maintained, and remain unchanged, which are three principles of corporate capital system.

\section{Evaluation on implementation effect of authorized capital system in Chinese Company Law}

\section{Benefits for China's implementing authorized capital system}

China's introduction of authorized capital system is the inevitable result of China's market economy development. The Company Law of 2005 adopts compromise capital system; on one hand, the legal capital system is implemented for joint-stock companies established through fund raising; on the other hand, the authorized capital system is implemented for limited liability companies and joint-stock companies established by means of sponsorship. From perspective of actual implementation effect of creditors' interest protection, the legal capital system doesn't fully realize the protection on creditors' interests, but induces common illegal behaviors such as withdrawal of capital and feigned investment. Through implementation of new authorized capital system, it is able to solve the difficulty of insufficient capital while the company is established by shareholders, promote the development of corporate economic entity and vitalize the economy to a bigger degree. Besides, it is able to determine the next step of corporate development direction according to the change of market environment.

\section{Drawbacks in China's implementing authorized capital system}

The creditors' interest protection is threatened from perspective of system construction.

In the traditional theory of company law, due to corporate profitability feature, more attention will be paid to shareholders' interests. The creditors belong to corporate external relationship and they are unrelated to corporate direct operation, thus the less attention will be paid to creditors' interests compared to shareholders' interests.

The authorized capital system depends on strong social credit mechanism and perfect capital market; while implementing this system, China adopts the principle that the efficiency comes first and gives no legal compulsory regulations on capital market and credit mechanism. Under China's special environment, on one hand, the authorized capital system makes corporate establishment become more convenient; on the other hand, it is very easy to cause credit crisis, including "briefcase company"(3) and other fraud conducts, which causes the situation that the creditors face credit crisis and their interests are difficult to be protected.

The creditors' interest protection is threatened from perspective of motive power of corporate profit-seeking.

The articles of association are the reflection of shareholders' will, and they have independent personality and self-oriented thoughts. The legal person's independent personality and shareholder limited liability system jointly promote rapid corporate and economic development. It is obvious that the authorized capital system adopts the concept that the efficiency comes first between efficiency and justice. Therefore, while there is any conflict between efficiency and justice, the justice will concede, thus the interest of partial justice will be damaged. The creditors' interests just belong to this type. In order to seek for efficiency and seek for maximum corporate interests, some companies transfer the legal person and shareholders' investment risk to the creditors through adding creditors' risk, weakening creditors' economic advantage and status and other methods.

\footnotetext{
(2) Jianwei,Li.Company Law(2nd edition,2011).China Renmin University Press.at 165.

(3) "Briefcase company" is a kind of company with no capital to operate its business.
} 


\section{Evaluation and reference to American authorized capital system}

The reason why the authorized capital system can promote a benign development of American corporate market is that America has more developed capital market and perfect legal system. ${ }^{4}$ These two factors promote the perfect combination of authorized capital system and American national condition.

\section{Perfect credit management mechanism}

American credit system plays a basic guarantee role in virtuous circle of authorized capital system. In America, there are many credit institutions, the citizens have high level of credit education, the social credit atmosphere is good, and the relevant laws and regulations are also perfect. Furthermore, the division of labor is clear in American credit management mechanism; except for federal and state government, the subordinate management organizations can also execute the power, thus this kind of "double-level multi-head" management system promotes the perfection of its credit punishment mechanism. ${ }^{5}$ Meanwhile, under the condition of supervision from credit service agencies and customers, and of open and transparent social credit information, once the behaviors of breaching promises happen in corporate operation, such company will suffer the regulation and punishment from state government.

\section{Restraint of information disclosure mechanism on fraud behaviors}

American information disclosure mechanism has been established and implemented in Securities Act of 1933, and it requires that all American companies shall disclose their financial information. This Act stipulates that all companies shall make a registration in securities exchange before issuing securities. Later, in the modification to Company Law and Securities Act, the adjustment is made for corporate financial information disclosure, and those laws require that all American companies shall perform the obligation of continuous open disclosure of corporation financial information so that the customers, investors, and corporate stakeholders can master valuable corporate financial information through network and telephone, including various financial conditions, credit and debt, operation condition, whether there is economic and legal dispute, etc. In this way, the companies have to disclose their financial information according to legal provisions and reduce the fraud behaviors such as "briefcase company”.

\section{Establishment of disregard of corporation personality and capital adequacy principle}

In order to protect the creditors' legal interests under authorized capital system, America establishes the system of "piercing the corporate veil" according to which the creditors can propose a request to the court about "piercing the corporate veil" to investigate the shareholders' joint liability in order to protect their interests. This is a kind of legal mechanism which can help creditors to disclose shareholders' some illegal economic behaviors. Except that, the case of Arnold v. Philip establishes the capital adequacy principle as supplement; if a company violates capital adequacy principle, it will face the risk of "piercing the corporate veil” due to lack of sufficient capital to maintain basic corporate operation. This endows the creditors with bigger space of safeguarding their legal rights.

Therefore, in America, the three systems, that is, “piercing the corporate veil”, credit system, and information disclosure system, jointly maintain and restrict the economic relation and balance among shareholders, legal person, and creditors in one company and protect the creditors' interests beyond corporate system to maximum degree.

\section{Measures on creditors' interest protection in Chinese authorized capital system}

Although America and China belong to different legal system and there is difference in their capital market and construction of laws-related supporting facilities, the theory of authorized capital system is basically consistent, thus there is also similarity in inherent defects of system. Therefore,

\footnotetext{
(4) Jianwei,Li.Company Law(2nd edition,2011).China Renmin University Press.at 166.

(5) Xiaoguang,Shang, “Analysis on Creditors’ Interest Protection under China’s Authorized Capital System -

Observation and Thought Based on Experience of American Company Law” , Legality Vision, 2015,02(middle),at 238.
} 
American mature construction method and experience of supporting facilities are of reference significance and they can provide China with the scheme to make up the deficiencies of this system.

\section{To pay equal attention to efficiency and justice}

The authorized capital system pays more attention to the principle that the efficiency comes first. Therefore, in order to guarantee the creditors' interests, it is required to establish a system which pays attention to justice principle beyond such system so as to balance the principle that the efficiency comes first, that is, a mechanism which both encourages corporate profit-seeking and guarantees corporate creditors' interests to realize a win-win situation.

\section{To construct credit system}

In order to protect creditors' interests and restrict the behaviors of breach of trust in all sectors in current society, China can take reference to American practices. Firstly, Chinese social credit mechanism is not perfect and still limited in different industry, and there is no complete and perfect credit investigation database system; therefore, it is required to quicken the construction of credit legislation and guide the construction of social credit system through laws in whole-society range. Secondly, as for the establishment of credit system, it is also required to include credit education into the national education so as to solve fundamental problem (credit crisis) from perspective of culture, belief, and ideology. Thirdly, the suitable credit evaluation mechanism shall be established; through evaluation, it is able to provide an objective evaluation on each company, which can help creditors to select enterprises. Fourthly, the strict punishment mechanism shall be established. Through investigating promise-breakers’ legal liability and increasing promise-breakers' promise-breaking cost, it is able to naturally let promise-breakers form the fear psychology to "promise-breaking".

\section{To perfect information disclosure system}

China's information disclosure system is still not perfect; the information disclosure system can be determined through legislation to enhance corporate legal obligation to disclose information and expand the content and path of corporate information disclosure. It is required to both pay attention to improving corporate internal level of self-discipline, and enhance corporate external supervision. The corporate internal self-discipline involves corporate internal organization management, and the laws can propose mandatory requirement for information disclosure. The external supervision includes government offices, social organizations, legal persons, and citizens, all of which can supervise corporate non-disclosure or false information disclosure or other behaviors so as to guarantee creditors' interests.

\section{To perfect disregard of corporation personality}

The advantage and disadvantage of authorized capital system are excessively flexible. The corporate operation system under authorized capital system has large autonomous space, but China still lacks of corresponding supporting credit mechanism, thus it is easy for the authorized capital system to be abused by companies or shareholders, thus damaging creditors' interests. In China, the disregard of corporation personality has certain limitation, for the limitation of creditors' cognition on corporate operation also determines that the actual application of the rule of "piercing the corporate veil" increases the creditors' burden. The capital adequacy principle determined in American case law can be used as reference to China, that is, suitably relaxing the restrictions while the "piercing the corporate veil" is applicable; however, while the creditors' interests are guaranteed, it is required to not challenge shareholder limited liability mechanism. Besides, it is able to create a virtual "control intermediary" between shareholders and creditors who abuse the control power, and such "control intermediary" can stand for the company to disregard the responsibility and regulation to creditors' behaviors, and also help creditors to disclose enterprise legal person's promise-breaking behavior, such as listing the corporate hotchpot and confusion of personality and stipulating the terms of revealing all the details.

\section{To enhance corporate social responsibility}

The corporate social responsibility system has been included in Article 5 of Chinese Company Law. The corporate social responsibility requires that the company shall bear necessary responsibility for the society, including creditors. This provision is over-general and abstract, and not specific, thus there exist large discretion and difficult execution in implementation process. Through legislation, it 
is able to elaborate corporate social responsibility, which can help to promote the companies to make up the loopholes left by authorized capital system and guarantee creditors’ interests.

\section{To enhance corporate internal management}

It is required to completely eradicate the shareholders and companies to abuse rights and utilize the loopholes of authorized capital system to implement various kinds of fraud behaviors which damage creditors' interests, which both depends on perfection of legal system and enhancing of social supervision, and depends on corporate internal scientific management. Through improving internal force, the companies can carry out legal and honest management on shareholders, directors, and senior executives' rights, thus it is the most direct means to protect creditors' interests.

\section{Conclusion}

Chinese corporate capital system gradually steps into authorized capital system, and this is the optimization of corporate legal environment and progress of ideology, but its high flexibility provides opportunity for many companies' fraud behaviors. Therefore, how to coordinate and promote corporate healthy development and truly guarantee the interests of corporate third party (creditors) through Company Law and relevant supporting mechanism is the goal we jointly strive for.

\section{References}

[1] Xudong,Zhao. Company Law, Higher Education Press, version 2008.

[2] Jianwei,Li. Company Law (2nd edition), China Renmin University Press, version 2011.

[3] Xiaobo,Tong. Research on Alleviation of Chinese Corporate Capital System and Creditors' Interest Protection, Xi'an University of Technology, 2007.

[4] Xinming,Li. Research on Legal Problems of Corporate Capital System on Creditors' Interest Protection, Heilongjiang University, 2009.

[5] Ning,Li\&Yan,Jiang. Analysis on Factors Restricting Realization of Authorized Capital System in China, Journal of Shenyang University of Technology (Social Science Edition), 2011, 04 (2).

[6] Xiaoguang,Shang. Analysis on Creditors' Interest Protection under China's Authorized Capital System - Observation and Thought Based on Experience of American Company Law, Legality Vision, 2015,02(middle). 